\title{
Cytotoxicity of Experimental Casting Alloys Evaluated by Cell Culture Tests
}

\author{
R.G. CRAIG and C.T. HANKS
}

School of Dentistry, University of Michigan, Ann Arbor, MI 48109-1078

The cytotoxicity of a series of 29 experimental alloys and six pure metals was determined with cell culture techniques and succinic dehydrogenase histochemistry. The width of any ring of inhibition, optical density of the histochemically stained cells, and a visual ranking of the intensity of the blue color of the stained cells were compared for determination of cytotoxicity. Twenty-four of the 35 metals and alloys $(\sim 70 \%)$ had the same rankings by the three methods. Of the pure metals, $\mathrm{Au}, \mathrm{Pd}$, and $\mathrm{Ti}$ were the least cytotoxic, followed by $\mathrm{Ag}$, then $\mathrm{Ni}$, and finally, $\mathrm{Cu}$. Single-phase alloys with moderately high $\mathrm{Cu}$ and without high Pd and $\mathrm{Au}$ concentrations had high cytotoxicity, as did multiphase alloys, even when they were high in $\mathrm{Au}$ and Ag. High Pd was more effective in maintaining the biocompatibility of alloys containing $\mathrm{Cu}$ than was Au. Singlephase alloys with compositions typical of those to be used for porcelain-fused-to-metal restorations showed good biocompatibility, as did those base metal alloys that formed adherent oxide surface layers.

\section{J Dent Res 69(8):1539-1542, August, 1990}

\section{Introduction.}

The cytotoxicity of a series of commercial dental casting alloys was determined by cell culture techniques (Craig and Hanks, 1988). Phase-contrast microscopy was used for examination of cell morphology and succinic dehydrogenase histochemical reaction for measurement of any ring of inhibition of fibroblasts around the alloys and any decrease in enzyme activity of the cells in the culture medium. That study found that crown and bridge gold casting alloys and a $\mathrm{Ni}$ - and a Co-based alloy were more biocompatible in the polished than in the as-cast condition. Porcelain-fused-to-metal alloys were biocompatible in either the as-cast or polished condition (Craig and Hanks, 1988).

Since the method appeared satisfactory for evaluation of cytotoxicity of alloys in direct contact with gingival tissues, a series of 28 experimental alloys, six pure elements $(\mathrm{Au}, \mathrm{Pd}$, $\mathrm{Ti}, \mathrm{Ag}, \mathrm{Ni}$, and $\mathrm{Cu}$ ), and an 18-8 stainless steel were tested by: (1) the ranking of the width of any ring of inhibition of cell growth around the alloys, (2) ranking of optical density of the histochemically stained cells, and (3) visual ranking of the intensity of the color of the histochemically stained cells.

The objectives of the study were: (1) to examine whether cellular responses to either elements or experimental alloys might explain the cytotoxicity of dental alloys, (2) to rank the biocompatibility of some pure elements found in dental alloys, and (3) to determine whether there was a correlation among the three methods of evaluation of cytotoxicity of the metals and experimental alloys.

\section{Materials and methods.}

The metals and alloys and the atomic percentage of elements present are listed in Table 1. The percentages of the elements

Received for publication November 8, 1989

Accepted for publication March 1, 1990 add up to $100 \pm 0.1 \%$, since the values calculated from the weight percentages were rounded off. Based on the principal atomic percentage, there were $15 \mathrm{Au}-, 7 \mathrm{Pd}-, 4 \mathrm{Ag}-, 1 \mathrm{Ti}-, 1$ $\mathrm{Cr}-$, and $1 \mathrm{Fe}$-based alloys, plus pure $\mathrm{Au}, \mathrm{Pd}, \mathrm{Ti}, \mathrm{Ag}, \mathrm{Ni}$, and $\mathrm{Cu}$; however, when the concentrations were calculated on the usual weight percentage basis, there were $17 \mathrm{Au}-, 5 \mathrm{Pd}-, 4$ Ag-, $1 \mathrm{Ti}-,, 1 \mathrm{Cr}-$, and $1 \mathrm{Fe}$-based alloys.

Samples were prepared as disks $5 \mathrm{~mm}$ in diameter and 3 $\mathrm{mm}$ thick having a stem $2.5 \mathrm{~mm}$ in diameter and $10 \mathrm{~mm}$ long extending from one face of the disk (Craig and Hanks, 1988). The disks were successively polished with an abrasive rubber wheel, and then with Tripoli and rouge on a rag wheel. The polished samples were ultrasonically cleaned for ten $\mathrm{min}$ in Jelenko Polishing Compound Remover diluted 1:3 with distilled water, then for ten min in distilled water, and finally for ten $\mathrm{min}$ in $95 \%$ ethanol. The samples were placed in 24 -well sterile culture dishes, sterilized with ethylene oxide for $24 \mathrm{~h}$, and then de-gassed under vacuum for one month prior to plating of the cells.

Cell culture testing with Balb/c $3 T 3$ cells was conducted according to previously described methods (Craig and Hanks, 1988) with six replications of each metal. Teflon was used for negative controls, and plasticized polyvinyl chloride was used for positive controls. Several wells without disks served as blanks with maximum cell growth and succinic dehydrogenase activity. Succinic dehydrogenase activity of the cells was evaluated by dinitrotetrazolium chloride histochemical staining (Pearse, 1972) three days after cells were plated.

Cytotoxicity of the alloys and pure metals was evaluated by: (1) measurement of the width of any ring of inhibition around the stained samples; (2) determination of the optical density (percent absorption) of the blue histochemically stained cells, compared with the center of the well containing no cells; and (3) visual ranking of the intensity of the blue of the histochemically stained cells. The width of the ring of inhibition was ranked 1 through 5 on a non-linear scale, with 1 being the smallest and 5 being the largest width, as shown in Table 2 . The optical density (on a linear scale) and the visual ranking (based on estimation of amount of color around samples) schemes are listed in Tables 3 and 4, respectively, and again a ranking of 1 was the best and one of 5 was the worst.

\section{Results.}

The rankings of all the alloys and metals by the three methods are presented in Table 5. The visual rankings were obtained by two independent observers; in three instances of disagreement, the rankings were discussed and agreement was reached. Metals or alloys not ranked the same by the three methods are underscored. Since the data are non-parametric, the ranking is not as powerful a comparison as with parametric data. Therefore, the most conservative ranking of the cytotoxicity of the alloys and metals is given in Table 6, where they are ranked with the highest numerical ranking of the three methods. These conservative rankings, although possibly unfair to a particular material, provide a safety factor for alloys used in patients.

For the pure metals, $\mathrm{Au}(30), \mathrm{Pd}(31)$, and $\mathrm{Ti}(32)$ were 
TABLE 1

ALLOY OR METAL NUMBER AND COMPOSITION

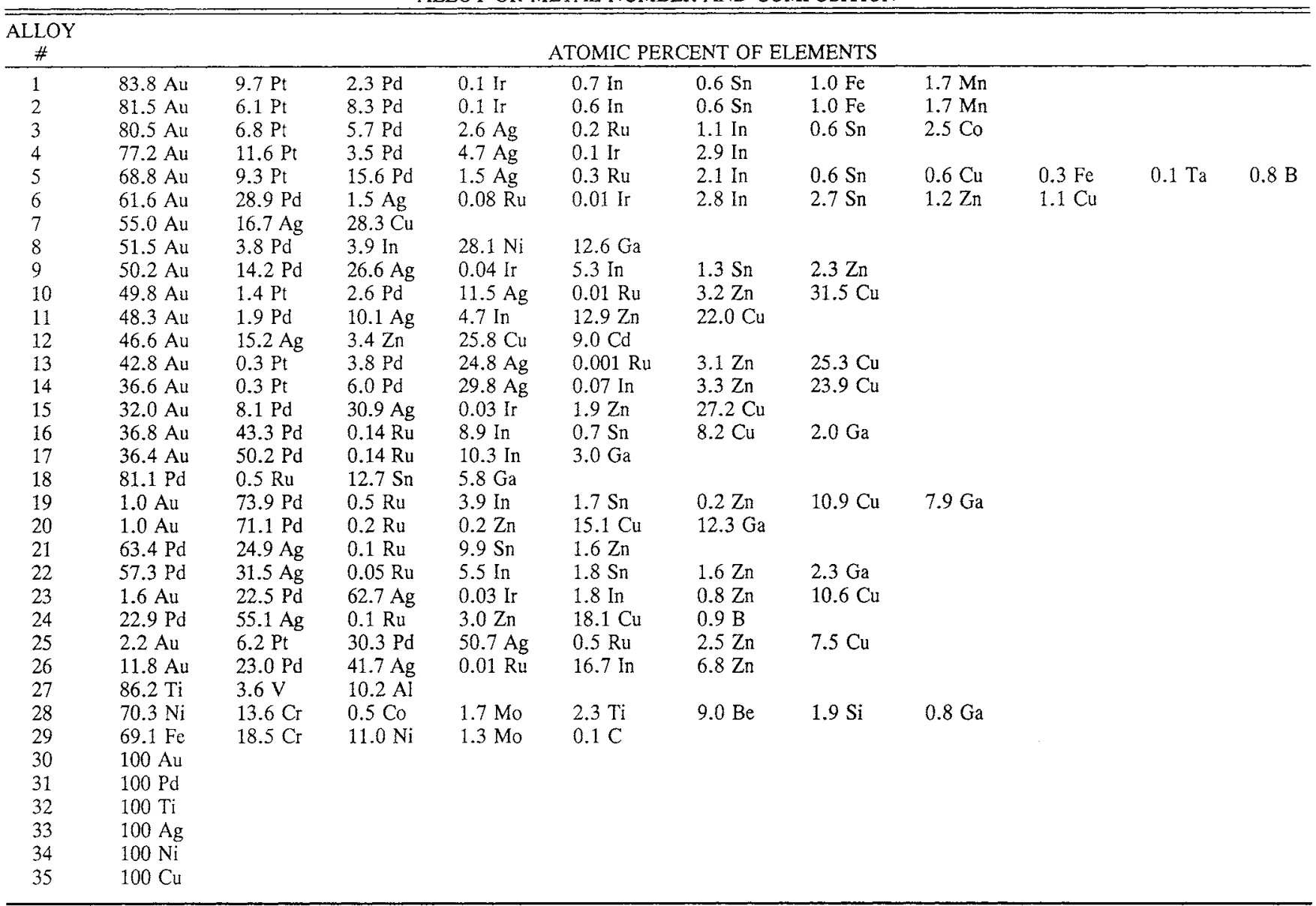

ranked 1 (least cytotoxicity), Ag (33) ranked 2, Ni (34) ranked 4 , and $\mathrm{Cu}(35)$ ranked 5 . For $\mathrm{Cu}$, all of the cells were not attached. For $\mathrm{Au}, \mathrm{Pd}$, and $\mathrm{Ti}$, there was no ring of inhibition.

The Ti-Al-V alloy (27), 18-8 stainless steel (29), and the $\mathrm{Cr}-\mathrm{Ni}-\mathrm{Ti}-\mathrm{Co}$ alloy (28) each had a ranking of 1 , and these alloys were not cytotoxic.

Other than pure $\mathrm{Cu}$, only one $\mathrm{Au}$ alloy (8) and one $\mathrm{Ag}$ alloy (25) had the poorest ranking of 5 , in spite of 51.5 at. \% (75 wt. \%) of $\mathrm{Au}$ in alloy 8 and 50.7 at. \% (49.5 wt. \%) of $\mathrm{Ag}$, 30.3 at. \% (29.2 wt. \%) of $\mathrm{Pd}$, and 6.2 at. \% (11.0 wt. \%) of $\mathrm{Pt}$ in alloy 25. Scanning electron micrographs showed that these were multiphase alloys, and an example is shown in Fig. 1. A third alloy (24) having 55.1 at. \% (61 wt. \%) Ag, 22.9 at. $\%$ (25 wt. \%) $\mathrm{Pd}$, and 18.1 at. $\%$ (11.8 wt. \%) $\mathrm{Cu}$ was ranked 4 , and it also was found to be a multiphase alloy, as shown in Fig. 2.

In general, alloys with from 36 to 50 at. $\%$ Au were ranked $4(10,12,13,14)$ and contained from 24 to 32 at. $\% \mathrm{Cu}$ with

TABLE 2

RANKING SCHEME FOR THE WIDTH OF THE RING OF INHIBITION OF CELLS AROUND THE METAIS

\begin{tabular}{cc} 
Rank & Width of Ring, mm \\
\hline 1 & $0.0-0.1$ \\
2 & $0.2-0.5$ \\
3 & $0.6-1.0$ \\
4 & $1.1-2.0$ \\
5 & $2.1-5.0$ \\
\hline
\end{tabular}

$12-30$ at. $\% \mathrm{Ag}, 0-6$ at. $\% \mathrm{Pd}$, and -3 at. \% $\mathrm{Zn}$. Alloy 12 contained 9.0 at. $\%$ of $\mathrm{Cd}$.

Alloys ranked 3 were Au alloys from 32-81 at. \% Au and $\mathrm{Ag}$ alloys with $42-63$ at. \% Ag. Alloy 15 (with 32.0 at. \% $\mathrm{Au}$ ) also had 8.1 at. \% $\mathrm{Pd}$ and 30.9 at. \% Ag, although it had 27.2 at. \% Cu. Alloys 11 and 7 had 48.3 and 55.0 at. \% Au,

TABLE 3

RANKING OF OPTICAL DENSITY OF HISTOCHEMICALLY STAINED CELLS

\begin{tabular}{cc}
\hline Rank & Optical Density, $\%^{*}$ \\
\cline { 2 - 3 } & $12-15$ \\
2 & $9-12$ \\
3 & $6-9$ \\
4 & $3-6$ \\
5 & $0-3$ \\
\hline
\end{tabular}

*Percent absorption.

TABLE 4

VISUAL RANKING OF COLOR OF HISTOCHEMICALLY STAINED CELLS

\begin{tabular}{cc}
\hline Rank & Color \\
\cline { 2 - 2 } & Dark blue \\
2 & Medium blue \\
3 & Pale blue \\
4 & Light blue \\
5 & Colorless \\
\hline
\end{tabular}


TABLE 5

RANKING OF ALL METALS AND ALLOYS BY THE THREE METHODS

\begin{tabular}{|c|c|c|}
\hline Rank & Method & Metal or Alloy* \\
\hline 1 & $\begin{array}{l}\text { Ring of inhibition } \\
\text { Optical density } \\
\text { Visual }\end{array}$ & $\begin{array}{l}1,3,4,5,6,9,16,17,18,20,22,27,28,29,30,31,32 \\
1,2,3,4, \overline{5}, \overline{6}, 16,17,18,19,20,22,27,28,29,30,31,32 \\
1,4, \overline{5}, \overline{6}, 17,18, \overline{19}, 20,22,27,28,29,30,31,32\end{array}$ \\
\hline 2 & $\begin{array}{l}\text { Ring of inhibition } \\
\text { Optical density } \\
\text { Visual }\end{array}$ & $\begin{array}{l}\overline{7,11}, \underline{19}, 21, \underline{26}, \overline{33}, \underline{34} \\
\overline{9}, \overline{21}, \overline{33} \\
\underline{2}, \underline{3}, \underline{9}, \underline{11}, 16,21, \underline{26}, 33\end{array}$ \\
\hline 3 & $\begin{array}{l}\text { Ring of inhibition } \\
\text { Optical density } \\
\text { Visual }\end{array}$ & $\begin{array}{l}2,13,15,23 \\
\overline{7}, \overline{10}, 11,15,23,26 \\
\overline{10}\end{array}$ \\
\hline 4 & $\begin{array}{l}\text { Ring of inhibition } \\
\text { Optical density } \\
\text { Visual }\end{array}$ & $\begin{array}{l}\overline{10,12}, 14,24 \\
\overline{12}, 13,14,24 \\
12, \overline{13}, 14,24,34\end{array}$ \\
\hline 5 & $\begin{array}{l}\text { Ring of inhibition } \\
\text { Optical density } \\
\text { Visual }\end{array}$ & $\begin{array}{l}8,25,35 \\
8,25,35 \\
8,25,35\end{array}$ \\
\hline
\end{tabular}

${ }^{*}$ Metals or alloys that are underscored were not ranked the same by the three methods.

with 22-28 at. \% $\mathrm{Cu}$ and $10-17$ at. \% Ag. Alloy 2, with the highest noble metal ( $\mathrm{Au}, \mathrm{Pd}, \mathrm{Pt}$ ) content of $\sim 96$ at. \%, also contained $\mathrm{Mn}, \mathrm{In}, \mathrm{Sn}, \mathrm{Fe}$, and $\mathrm{Ir}$ in quantities of $1.7,0.6,0.6$, 1.0 , and 0.1 at. \%, respectively.

Alloys ranked 2 were high-Pd or high-Au-Pd alloys (65-94 at. \%), with alloys 9 and 21 having 25-27 at. \% Ag and $\sim 2$ at. \% $\mathrm{Zn}$, and alloys 16 and 19 having 8-11 at. \% $\mathrm{Cu}$. The alloys ranked 1 were noted for their high Au and/or Pd content and lack of $\mathrm{Cu}$, except alloy 20 , with 15.1 at. \% $\mathrm{Cu}$, which also contained about 71 at. \% Pd.

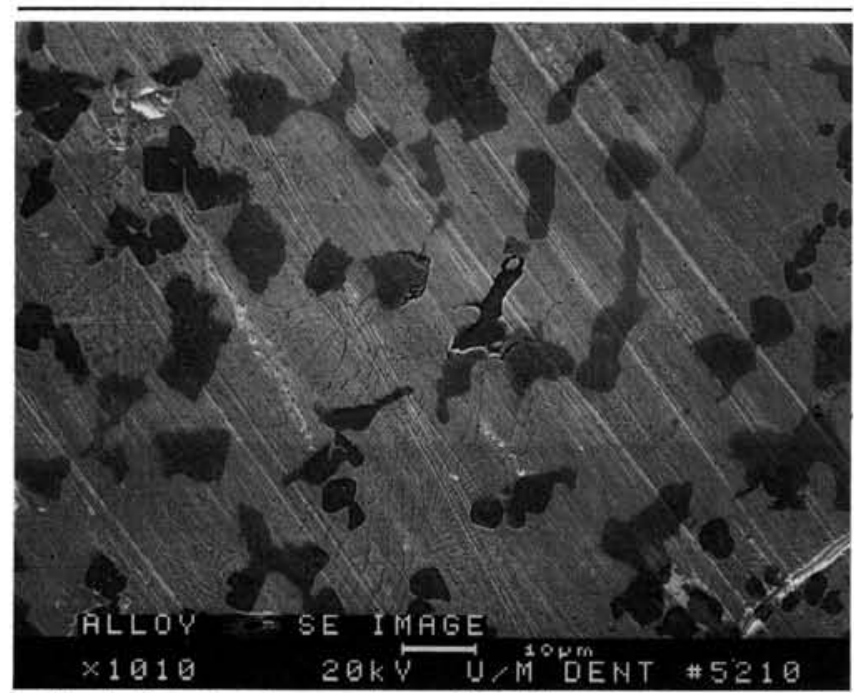

Fig. 1-Scanning electron micrograph (SEM) of alloy 8 containing 51.5 $\mathrm{Au}, 28.1 \mathrm{Ni}, 12.6 \mathrm{Ga}, 3.9 \mathrm{In}$, and $3.8 \mathrm{Pd}$ (at. \%). The dispersed phase contained $\mathrm{Ni}$ and $\mathrm{Ga}$, the matrix phase consisted of $\mathrm{Au}$ and $\mathrm{In}$, and $\mathrm{Pd}$ was segregated.

TABLE 6

OVERALL RANKING OF METALS AND ALLOYS USING THE MOST CONSERVATIVE (HIGHEST) RANK

\begin{tabular}{cc}
\hline \hline Rank & Metal or Alloy \\
\cline { 2 - 2 } 1 & $1,4,5,6,17,18,20,22,27,28,29,30,31,32$ \\
2 & $3,9,16,19,21,33$ \\
3 & $2,7,11,15,23,26$ \\
4 & $10,12,13,14,24,34$ \\
5 & $8,25,35$ \\
\hline
\end{tabular}

\section{Discussion.}

The cause of the high biocompatibility of $\mathrm{Au}$ and $\mathrm{Pd}$ was probably their high nobility, while the high biocompatibility of Ti was probably related to the formation of a highly adherent layer of $\mathrm{TiO}_{2}$ on the $\mathrm{Ti}$ samples. The lower nobility of $\mathrm{Ag}$ most likely contributed to its ranking of 2, and the lack of an adherent oxide layer on $\mathrm{Ni}$ plus its lack of nobility resulted in a ranking of 4 . The ready dissolution of $\mathrm{Cu}$ in the culture medium contributed greatly to its cytotoxicity and the ranking of 5 (Bumgardner et al., 1989; Lemons et al., 1988; Wataha et al., 1989).

The high biocompatibility (ranking of 1 ) of Ti-Al-V (alloy 27), 18-8 stainless steel (alloy 29), and $\mathrm{Ni}-\mathrm{Cr}$ (alloy 28) containing $\mathrm{Ti}$ was probably related to a protective oxide layer of $\mathrm{Cr}$ and/or Ti. However, Meyer et al. (1989) showed that alloys 28 and 29 had low breakdown potentials of $0.2-0.3$ volt from anodic polarization measurements, and thus, these alloys would

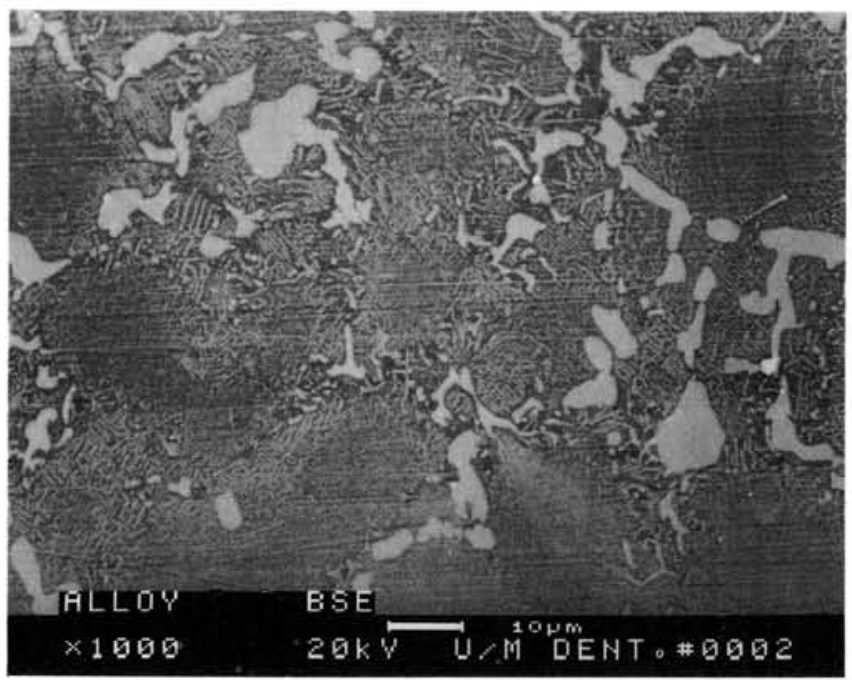

Fig. 2-SEM of alloy 24 containing $55.1 \mathrm{Ag}, 22.9 \mathrm{Pd}, 18.1 \mathrm{Cu}, 3.0$ $\mathrm{Zn}, 0.9 \mathrm{~B}$, and $0.1 \mathrm{Ru}$ (at. \%). The large dark areas are $\sim 59$ at. \% Ag, $\sim 19$ at. \% Pd, $\sim 19$ at. \% $\mathrm{Cu}$, and $\sim 3$ at. \% $\mathrm{Zn}$. The light, rather largc areas are high in Pd (50-70 wt. \%), moderate in $\mathrm{Cu}(16-25$ wt. \%) and $\mathrm{Zn}$ (12-19 wt. \%), with small amounts of $\mathrm{Ag}$ (6-11 wt. \%). Eutectic-like light areas have $\mathrm{Ag} / \mathrm{Cu}$ and $\mathrm{Ag} / \mathrm{Pd}$ of $\sim 2 / 1$. 
be expected to have different and poorer biocompatibility under conditions of electrical potentials. These data illustrate that surface rather than bulk composition is critical in the evaluation of cytotoxicity.

The high cytotoxicity (ranking of 5) of Au alloy 8 and $\mathrm{Ag}$ alloy 25 was most likely a result of their being multiphase alloys that would reduce their resistance to corrosion. This statement is supported by their low anodic polarization breakdown potentials of 0.3-0.4 volt (Meyer et al., 1989). Alloy 24, a Ag-Pd-Cu alloy, was also found to be multiphase, and it had a ranking of 4 and a low breakdown potential of 0.35 volt. The use of multiphase alloys of $\mathrm{Au}$ or $\mathrm{Ag}$ should be avoided if good biocompatibility is to be obtained.

The alloys containing 36-50 at. \% Au and small amounts of $\mathrm{Pd}(<6$ at. \%) were not sufficiently noble in the presence of 24-32 at. \% $\mathrm{Cu}$ and 3 at. \% $\mathrm{Zn}$ (alloys 10, 12, 13, and 14), and thus had rankings of 4 . It should be pointed out that alloy 12 also contained 9.0 at. \% $\mathrm{Cd}$, an element known to cause incompatibility.

Single-phase alloys that were high in $\mathrm{Au}$, and especially $\mathrm{Pd}$, were effective in providing compatibility in the presence of about 25 at. $\% \mathrm{Ag}, 2$ at. $\% \mathrm{Zn}$, and 15 at. \% $\mathrm{Cu}$ (alloys 9, 20 , and 21 ).

A number of the alloys $(1,2,4,5,6,16,17,19,21,22)$ were ranked 1 or 2 by at least one test measure, and these would be useful for porcelain-fused-to-metal restorations, since they contained In and sometimes $\mathrm{Sn}$ for metal-ceramic bonding, and very little or no $\mathrm{Cu}$ to control color of the ceramic.

Although speculative at this point, these cytotoxicity tests are interpreted to mean that alloys ranked 4 would not be recommended for use as dental alloys. In an area where a crown comes into contact with gingival tissue, the presence of alloys capable of causing cytotoxicity would contribute to necrosis of the tissue, which would be very difficult to differentiate from the effects of bacteria and plaque. Alloys ranked 5 should be eliminated from use as dental alloys. On the other hand, alloys ranked 1 and 2 should be highly biocompatible against gingivae. Since this test for cytotoxicity is highly sensitive, alloys ranked 3 by one method would in all probability be biocompatible for purposes of dental restorations if the rank was the same or lower by the other two methods. For example, alloy 2 is most likely biocompatible, even though it was ranked 3 by the ring of inhibition, since it was ranked a 2 by the visual method and a 1 by the optical-density method.
The data presented do not prove which elements are causing incompatibility. They do show that cytotoxicity does not correlate well with wt. \% or at. \% of any single element. Furthermore, they suggest which elements and conditions should be investigated by analysis of the culture medium surrounding the alloys or metals. The advantage of the ring of inhibition and optical-density method is that a quantitative value is obtained which permits easier statistical treatment of the data. Of these two methods, the optical-density method is not as susceptible to artifacts such as variations in the width of the ring around the circumference of the sample. Although the visual method provides only a ranking, it results from an estimation of overall intensity of the stained cells and minimizes the influence of artifacts of non-uniform plating of cells.

\section{Acknowledgments.}

We acknowledge the assistance of Chris A. Edwards in producing the SEM photographs and conducting the electron-dispersive analysis of the alloys. We also express our appreciation for partial support of the study by Metaux Precieux Sa Metalor, Neuchatel, Switzerland.

\section{REFERENCES}

BUMGARDNER, J.D.; LUCAS, L.C.; and TILDEN, A.B. (1989): Cell Culture Analyses of Aluminum-Bronze and Aluminum-Brass Alloys, $J$ Dent Res 68:322, Abst. No. 1123.

CRAIG, R.G. and HANKS, C.T. (1988): Reaction of Fibroblasts to Various Dental Casting Alloys, J Oral Pathol 17:341-347.

LEMONS, J.E.; LUCAS, L.C.; HENSON, P.; and HILL, C. (1988): Biocompatibility of Copper Base Alloys, $J$ Dent Res 67:262, Abst. No. 1196.

MEYER, J.M.; CRAIG, R.G.; SCHMALZ, G.; and RECLARU, L. (1989): Corrosion Resistance and Biocompatibility of Some Low Gold Dental Casting Alloys, European Dental Materials Conference, University of Glasgow, Scotland, Sept. 8.

PEARSE, A.G.E. (1972): Histochemistry; Theoretical and Applied, Vol. 2, 3rd ed. Baltimore: Williams and Wilkins Co., p. 1343.

WATAHA, J.C.; CRAIG, R.G.; and HANKS, C.T. (1989): Analysis of Culture Medium for Elements Dissolved from Casting Alloys, $I$ Dent Res 68:322, Abst. No. 1122. 